\title{
Ethnonationalist Capitalism \& The Illegitimate Legacies of the Yugoslav Wars
}

\author{
Faruk Hadžić ${ }^{a}$, \\ a Independent Researcher, Bosnia and Herzegovina, faruk.hadzico1@gmail.com, \\ https://orcid.org/0000-0003-1158-7858
}

ARTICLE INFO

Research Article

2021, Vol. 3(2), 87-108

e-ISSN 2667-5927

Article History:

Received: 04.01.2021

Revised: 21.04.2021

Accepted: 28.04.2021

Available Online: 30.04.2021

JEL Code: F50, F51, F59

Keywords: political economic transition, ethnonationalism, illegitimate economy, capitalism, former Yugoslavia, Yugoslav wars
Ethnonationalist Capitalism \& The Illegitimate Legacies of the Yugoslav Wars

Abstract

The author explores how the political and economic transition and the legacies of conflicts produced the states' criminalization and whether the more significant issues of these countries were nationalism or capitalist exploitation, or are these two categories in symbiosis? The presence of capitalism as the ruling model requires some form of nationalism and national identity- where a certain capitalist elite pragmatically chooses to build a nation-state, effectively mobilize and homogenize the rest of society on its platform. Ethnoational identities are formed as part of ethnonational-political projects, and national projects imply creating or completing nation-states that lead to the conflict. Local orders based on ethnic-violence turned into open war economies and entering into dynamic and symbiotic relations with illegal global markets and liberal market structures. The critical issue is the consolidation of mutual trust between the phenomena of "politicization of crime and criminalization of politics." Politically sensitive cases dealing with corruption, organized crime, or abuse of power are particularly vulnerable to various influences, and therefore it is vital to pass judgments to make existing records credible. Political and economic transformation cannot be fully accomplished due to disagreements between the economic and political spheres that would thwart the functioning of democratic institutions because the consolidation of the democratic order and the establishment of a market economy are in the balance of incompleteness. Re-establishing social structure and social ties, developing plurality and legality, is crucial as social security, once the most critical issues are met.

To cite this document: Hadžić F. (2021). Ethnonationalist Capitalism \& The Illegitimate Legacies of the Yugoslav Wars. BILTURK, The Journal of Economics and Related Studies, 3(2), 87-108.doi: 10.47103/bilturk.853746 
Hadžić F. (2021). Ethnonationalist Capitalism \& The Illegitimate Legacies of the Yugoslav Wars. BILTURK, The Journal of Economics and Related Studies, 3(2), 87-108.doi: 10.47103/bilturk.853746

\section{Introduction}

There is no doubt that in the turbulent history of the Balkans, the war marked every turning point: the creation and disintegration of states, kingdoms, empires; emergence and disappearance of new ideologies and economies; cultural revival and decay; adoption and loss of religions, beliefs, and customs. In the former Yugoslavia, or a semantically neutral name, the Balkans, the ambitions of some, especially more abundant ethnic nationalisms, often stimulated the imagination to unite the whole area under one self-proclaimed people and denomination, which in turn would lead to war, ethnic cleansing and destruction. The fundamental core of the political order in the former Yugoslavia was the system of charismatic power and legitimacy. As Weber has shown in his systematic sociology of rule (Deflem, 2012) , this type of order carries more significant opportunities for self-destruction than political regimes based on traditional or rational authority. Yugoslav society was faced with a tendency to degrade authority, which was still carried out with the legitimation formula of the former ruler ("Even after Tito, Tito"). In the type of political regime in which Tito was the primary factor of stability and the figure around which the normative consents of members of the political community were formed, which essentially compensates for the active consent of the "repressed civil society," the degradation of a central government authority. This process opened and upset the dead balance between the inherited political oligarchy of the post-Tito regime, Serbian political leader Slobodan Milosevic. In this region, the figure of the "gang" leader sometimes coincided with the figure of a political leader. The connection between violence, politics, illegal economy and criminal activities given the historical facts is present from the routes of smuggling opiates, weapons, funds needed for frequent anti-Turkish riots, in which individuals often controlled parts of the territory. It opened a model that seems to last, such as the assassination of Serbian Prime Minister Z. Đinđić in 2003. If we accept, in part, some thesis about the crucial role of organized crime in the emergence of modern states, there is an intertwined complex of seemingly unrelated phenomena. All these components are in varying degrees of interaction: illegal economy and organized crime control part of the territory (Zemun $\mathrm{clan}^{1}$ ) ), the wars of the 1990s, and nationalist politics.

The fact is that after the Second World War, socialist Yugoslavia became a kind of European success story. Between 1960-1980, it had one of the highest economic growth rates in the world, a decent standard of living, free medical care and education, a guaranteed right to work, one of the most respected passports, onemonth paid vacation, a literacy rate of over 90 percent, and a life expectancy of 73 years. In terms of living standards and freedoms ahead of most Eastern European countries and certain branches of the economy ahead of some Western European countries. After Tito's death, the biggest problem was that communism was not replaced by civil democracies, but ethnonational ones. The most obvious indicators

${ }^{1}$ The gang's power and influence peaked between $1999-2003$, and they were considered the most influential organizations in Southeast Europe.

BILTURK Journal of Economics and Related Studies 
of a serious economic crisis were inflation and huge external debt, exacerbated by a sharp jump in the value of the dollar. Thus, in the early 1980s, there were major disturbances in the economic life of the country. (Glavan, 2013) However, the contradictions between the political and economic spheres did not enable Yugoslavia's self-transformation to be carried out in a pacified manner. Under the onslaught of Ante Markovic's government's neoliberal reforms between 1989 and 1990, more than a thousand companies went bankrupt. It can be added that the dismantling of Yugoslavia as a structural possibility existed before, but the question of the modality of that event after Milosevic's appearance was brought to the surface with all its might. We are talking about violence as a form of the disintegration of Yugoslavia and its far-reaching consequences that can still be recognized today. Thus, the disintegration was not only the result of state failure, as the phenomenon is treated in the relevant theoretical literature, but an expression of a complex mix of exogenous and endogenous dynamics. (Milliken \& Krause, 2002: 33) We can follow cumulative events that are retroactively linked into a causal sequence: „the first forms of manifestation of the crisis of ideological production of reality, signs of exhaustion of the different specifics of the Yugoslav path were the breaking of liberalization in the seventies (with the projection that national orientations can be pacified within a monolithic political structure), the dissolution of earlier economic opportunities conflicts between centripetal and centrifugal tendencies, which ended with the deconstruction of an increasingly empty central authority, the competitive "game" of national elites, the failure to integrate certain entities into the Yugoslav project (especially Albanians, which became explicit in the 1980s), division of space according to the constellation of power (inconsistent regionalization that fueled nationalism), mobilization of populist energies in the context of the late 1980s with reference to the war environment of the 1990s, "democratization" of nationalism by spilling ethnic codes from party structures into the streets." (Woodward, 1995) Moreover, most political leaders engaged individuals from dubious criminal status, openly known criminals, as their official security, and criminals were often part of political assemblies. Many war commanders emerged from the wars as national heroes, and in the post-war period, became known for illegal enrichment, closely related to power structures. (Čabaravdic, 2008) Many criminals were members of the secret services. These services gained sufficient power and knowledge for violent "crisis management". In parallel with the wars in the former Yugoslavia, which left behind hundreds of thousands of dead, wounded and displaced, excellent business cooperation flourished in which the state, military, intelligence, and criminal circles of the warring parties earned wealth.

The question arises, whether the more significant issue of these countries is ethnonationalism or capitalist exploitation? Or are these two categories in 
symbiosis? In principle, the author argues that one arises from the other. The fact is that in post-socialist societies at the end of the 20th century, nationalism rose sharply - with the establishment of nation-states and the disintegration of all complex, non-nation-states - coincided with the rise of capitalism². In both historical and social contexts, the ideology of nationalism served as a screen to legitimize the appropriation of most economic resources and the takeover of the entire state apparatus by one social class, the growing class of capitalists. Within this ideological construct, with the help of a simple logical trick, this social class's partial interests are a priori legitimized by being presented at the nominal level as the universal interests of the whole society. Thus, the state and its economic resources function at the nominal level as the sovereign possession of the personification called the "nation," while at the actual level, they function as the sovereign possession of the class that created it.

The most critical question is how all the ruling systems that have emerged on the scene are in their essence of ethnopolitics. The answer to that question lies in the constitutive role of war for every policy. The existence of more ethnic nations implies more narratives of power and circulation in public opinion. (Bhaba, 1990: 128)

Nationalism in non-Western European countries - which includes countries of the former Yugoslavia has some specific characteristics. Due to the prolonged presence of late feudal empires (Habsburg, Ottoman, and Romanov) in their territories, nationalism appeared relatively late. As such, nationalist discourse in non-Western countries has not been consolidated in daily-routine, non-excessive forms - just like capitalism, which generally remains at the level of excesses that characterize the so-called "initial accumulation of capital." Fear of losing identity within multinational communities, such as Yugoslavia, after disintegration led to the sudden "emergence" of antagonistic individual national identities, becoming indivisible, and exclusive. (Hadžić, 2020: 3) Thus, a specific (extremely negative) characteristic of the post-Yugoslav space is that religions are identified with nations (majority). National identities built and consolidated with the help of such confessional exclusivism (usually associated with ethnic) manifested themselves as extremely impermeable and inflexible, and the rivalry between their national umbrella projects as almost irreconcilable. Therefore, this form of nationalism maintained a firm position in these societies' political processes. After their return to the capitalist orbit, it occupied the very center of political events. However, nationalism is essentially a transclass ideology that originated in the 19th century (there were no real nations before that). Its function is to connect all people living in newly created nation-states, capitalist states into one "imaginary community" both rich and poor, capitalists and workers. The reason is apparent - to prevent

\footnotetext{
${ }^{2}$ With the fall of the Berlin Wall and the universal spread of neoliberal capitalism in the countries of the former communist bloc, the non-national principle of state organization and the universal spread of the nation-state model were abandoned in this part of the world. 
class struggle, i.e., the rebellion of the workers against capital, the rebellion of the poor against the rich, is an invented ideology that ostensibly connects the poor and the rich, labor and capital. Nationalism has, from the very beginning, served precisely to quell all social and class struggles for a better society." (Tijardevic, 2016) Besides, in addition to the interests of international financial institutions, there was another interest, and that was the interest of those who implemented the required measures and created economic policy. Thus, domestic economic policy was, in fact, between the pressure of capital and the interests of nationalist political structures. One of the consequences of this situation was corruption - systematic corruption.

Furthermore, the symbiosis of nationalism and capitalist exploitation is evident, not only on the example of observed transition states, but it is increasingly shown on a global scale, and some critical positions around the new neoliberal imperialism, especially around EU imperialism, are beginning to be articulated. According to the relevant authors is a new type of anti-business. The nationalization of states prepared the ground for the entry of capitalism - ethnonationalism and ethnoreligious violence played a crucial role, as a foundation for criminalization. Starting from the war accumulation of capital (profiteering), through the privatizations of the 1990s, to the formation of power within ethnopolitics (especially war parties. Ethnic-confessionally homogenized nations born on the ruins of the socialist Yugoslav federation were conceived in tribal hatred, crime, and the privatization of the vast wealth and resources of the socialist era created by tens of millions of people as social property. (Perica, 2018) Thus, countries in the region became "captured by private interests by confiscation of the cultural property and transfer of that property to the thin layer of war profiteers, the former technocratic layer of the ex-Yu, the domestic political elite and foreign tycoons." (Tabakovic, 2007) The black economy in all countries has left visible changes in the social structure of the population; contributed to the impoverishment of a large part of the population. Economic empires of war and post-war actors were created, which were mainly enriched by the smuggling of excise goods banned from trade. (Hadžić, 2020: 258) This situation resulted in the long-term disintegration of the social order and the erosion of the legitimacy of states.

This area is characterized by extreme fragmentation of states originating from the beginning of the crisis at the end of the last century within the historical reasons, geopolitical periphery, and "entities" defined in ethnoreligious conflicts. The tragic circumstance for all Balkan nations and states is that peace, more precisely nonwarfare between them, now as in the past, is guaranteed only by the great powers. Today, ex-Yu countries show elements of "captured states" with interrelated negative influences on conflict, economic and sociopolitical transformations. The author suggests that the primary determinant of the captured state is corruption 
and a dysfunctional government that cannot implement the reforms necessary for its functioning. In terms of corruption, at the highest levels of politics leads to the capture of institutions- "captured state," which, according to R. Karklins, is reflected in the entire state's takeover by cartels consisting of political elites and economic oligarchs. (Karklins, 2005: 219) They are captured and made politically expedient, but not socially influential, by legislative, executive, judicial instances, and regulatory agencies and prosecuting authorities which, depending on the political interest, abuse the principle of prosecution opportunism." (Stoljiković, 2013: 135) The European Commission, which usually uses diplomatic language, stated in 2018/2019 report, that the countries of the Western Balkans show clear elements of state capture, including links to organized crime and corruption at all levels of government and administration and a strong intertwining of public and private interests. Moreover, the assessment of these countries by the Freedom House organization (2018), Serbia, BiH, Kosovo, and North Macedonia are transitional, hybrid regimes; regimes that have elements of democracy but also authoritarianism, speaks enough about the fact that these countries face important issues, which diminishes political, social, and economic opportunities in the modern world. ${ }^{3}$. In the Serbia, the executive dominates all aspects of political life, ignores the constitution and laws, and plays with the legislature and the judiciary and newly established regulatory agencies. (Vladisavljevic, 2011: 205) Historical and political circumstances, primarily war events, have contributed to the Balkans, including Croatia, being defined as a "derailed transition," where the nation-state's formation took precedence over democratic change and the difficult legacy of communism and economic backwardness. M. Kasapović states that the war made the transition processes in the country second-rate because the formation and defense of the newly formed state gained a clear advantage over the transformation of political and social life and that Croatia often moved from transitional to war studies, where war not only significantly surpassed transition processes, rather than making them opaque. (Kasapovic, 2001: 17) The economic situation has only partially improved, thanks to EU funds, in Croatia. However, in the long run, the system has caused the largest exodus of the population, reducing the tax base and jeopardizing pension health systems. A recent survey (2018) in Croatia shows that the main reasons for mass emigration are "an unorganized and corrupt state." (Juric, 2018) Slovenia, the first ex-Yu EU member, since 2004, does not have a high level of corruption, widespread clientelism, partisanship, lack of strategic vision, and is evenly developed. Although the former Slovenian Prime Minister was convicted of

3 See: Freedom House, 2018., 2017., 2016., Nation in Transit Bosnia and Herzegovina https://freedomhouse.org/report/nations-transit/2018/bosnia-and-herzegovina

Freedom House, 2018., 2017., 2016., Nation in Transit Croatia, https://freedomhouse.org/report/nationstransit/2018/croatia,

Freedom House, 2018., 2017., 2016., Nation in Transit Kosovo https://freedomhouse.org/report/nationstransit/2018/kosovo

Freedom House, 2018., 2017., 2016.,Nation in Transit Serbia https://freedomhouse.org/report/nationstransit/2018/ 
corruption, Slovenia has a perception of corruption of over $60 \%$, while, say, Croatia, to $48 \% .{ }^{4}$.

\section{Aim and Method}

The multidisciplinary approach to critical analysis aim to provides insights into understanding how the political and economic transition and the legacies of conflicts produced the states' criminalization, and whether the more significant issues of these countries were nationalism or capitalist exploitation? Or are these two categories in symbiosis? The critical analysis provides insights into understanding the extent to which the study's topic and phenomena are addressed as an essential factor. The literature review highlights knowledge and research gaps and identifies relevant initiatives.

\subsection{Economic and Political Transition of the Former Yugoslavia}

In the history of Eastern and Central Europe in the nineteenth and early twentieth centuries, it has been observed that in each of the countries, individuals appeared who had a huge influence on the outcomes. It is possible to imagine different outcomes with different key political actors in leading roles in such a context. Furthermore, what was right for the nineteenth century, namely, that "in the Balkans, the introduction of the state according to the European model came in a social situation that was almost completely unprepared for it" (Stoke, 1986), is equally valid and for the introduction of democratic institutions, rules and procedures at present. In most former republics, the state is still used by the main political protagonists more as a means of monopoly and less for a reasonable rule. "It is not surprising, therefore, that they are constantly interfering in the day-to-day functioning of politics, seeking to create personal regimes."(Stoke, 1986) E. Fraenkel (1952) used the theoretical construct of the dual state. However, when we study this model a little more thoroughly, we discover that behind this form, in essence, lies the regime of privatized power behind the facade of (non-existent) state. The dual Nazi state was a system of privatized power. Its essential mark was the dissolution of society's political fabric and the non-political nature of political processes. On the other hand, this dualism at the level of the constituent and formative principles of the order is expressed as a unique conflict between democratic legitimacy and facade legality in the former Yugoslavia. Moreover, this area is characterized by extreme fragmentation of states originating from the beginning of the crisis at the end of the last century within the historical reasons, geopolitical periphery, and "entities" defined in ethnoreligious conflicts. (Hadžić, 2020: 14)

\footnotetext{
${ }^{4}$ Transparency International corruption perception index 2018, https://www.transparency.hr/hr/clanak/indekspercepcije-korupcije-2018-48-bodova-60.mjesto/718
} 
The economic approach is not limited to explaining the behavior of those who have power and who are only interested in satisfying their interests (Lock, 2002), but also indicates that when applied from a theoretical perspective, system, that civil wars are processes with their dynamics. Simultaneously, the critical moment is the ambiguity of the circumstances related to the relationship between the state and the war. This ambiguity cannot be removed, and it will be enough to look at, say, the situation in Serbia in the 1990s: the state becomes an instrument of ruling elites, there is a union of state and regime and constant interference of administration and state, expanded clientelism, Caesarist codes of government, financial oligarchy. It increasingly announces dissatisfaction at the end of the millennium) and the deterioration of the social fabric. Within the notion of "captured states," we can speak from the social property, which is privatized by post-war "tycoons;" supporting authoritarian rulers linked to kleptocracy as a strategy to maintain stability undermines the EU accession process. Taking active funds is possible due to legal omissions in the process of transition. Pavlović calls this type of devastation of the state "tunneling of resources from companies" (Pavlovic, 2006), where companies are devastated by the transfer of assets and profits in favor of the majority ownership that is already owned by a private company.

The leading politicians in the countries of the former Yugoslavia have repeated the mantra over the past three decades that not enough has been done, that reforms have been insufficient so far, and that only one more step needs to be taken to bring the Balkan periphery to that capitalism as we can observe in the countries of the center. Contrary to this highly idealistic and nearly utopian approach, according to which capitalism is seen as an ideal that must be realized in that pure form in order to, in fact, bring everything it is believed to bring, we will try to offer another approach in which capitalism is viewed as realistically existing capitalism. According to this understanding, the period characterized as transitional should be analyzed as a period in which capitalism is already there, being established by the abolition of social ownership, workers' self-government, and the state's withdrawal from the position of equal economic actor. Capitalism understood in this way does not bring the same positive results expected from it as an ideal model, but (necessarily) implies unequal development and existence of countries in which high unemployment, poverty, consumption, low wages, scarce or non-existent technology, almost complete absence industries, and a poorly skilled workforce, as well as many non-economic social problems.

We have already problematized the symbiosis of nationalism and capitalist exploitation in the introductory part. In the post-Yugoslav area, there is still a fascinating combination of privatization and so-called state-owned enterprises, among which there is no difference in terms of the nature of the capitalist structure of their activities. In this sense, there have even been attempts outside for some stumbled companies to return partly to state ownership, but this does not change their so-called capitalist structure. It is the classic capitalist structure of the 
economy. It is about the character and very being of this neoliberal capitalist project with only one goal: profit for the vast minority and the impoverishment of the vast majority. In the case of Yugoslavia, this space was predetermined by a high degree of decentralization on the formal institutional level, never achieving social integration and nationalist policy in the institutional constitution of federal units and the informal political mobilization of support for rivals directly-post communist rule.

The nationalization of states prepared the ground for the entry of capitalism ethnonationalism and ethnoreligious violence played a crucial role, as a foundation for criminalization. Starting from the war accumulation of capital (profiteering), through the privatizations of the 1990s, to the formation of power within ethnopolitics (especially war parties. The "nation" is conceived as a virtual sovereign, as personification that simulates the being of the whole society and through which that being is realized in the form of sovereignty, and thus the ultimate source of social and political legitimacy is placed in the "nation"; the capitalist class takes control of the state apparatus and ownership of economic resources, the state and its economic resources thus function at the nominal level as the sovereign possession of the personification called the "nation," while at the de facto level, they function as the sovereign possession of the class that created it. Besides, as an available place, former Yugoslavia societies carry the specificity that ethnic or national identity is most closely linked to religion. The basis for the conflict was effort to realize one national - political project to the detriment of another, that is, to complete one nation-state to the detriment of another. However, having once entered the phase of active struggle for territories, nationalpolitical projects, according to their internal logic, according to the system of connected vessels, can hardly give up the struggle to complete national territories and nation-states until they eventually experience a convincing defeat by other national projects. Such a mechanism is inevitable as long as nation-states represent an unquestionably given norm within the global capitalist system. Attempts to create nation-states have, as a rule, caused mutual violence between different national groups. Without imaginatively developed democracies with all their legal and political potential, the ethnic-religious construction of nations creates an environment for further destabilization of society and deepening conflicts among ethnic groups. (Smith, 1998: 22)

An enviable level of corruption developed since the 1990s. Thus, the well-known phrase bribery and corruption, which is an integral part of the Balkan reality, has paradoxically become an appropriate mythological image that delegitimizes the Balkan disordered or post-communist corrupt transitional collectivity. (Vujic, 2019) Apart from the interests of international financial institutions, there was another interest, and that was the interest of those who implemented the required 
measures and created economic policy. Thus, domestic economic policy was, in fact, between the pressure of capital and the interests of political structures; one of the consequences of this situation was corruption. It is clear that it is a transitional structural phenomenon.

The point is that in the situation of introducing a capitalist economy of the most liberal type with intense competition, the group of individuals who carried out the liberalization itself had a favorable position to facilitate the entry of large capital. Given the poor prospects of the domestic economy and foreign players' strength, this proved to be the most rational way to acquire start-up capital with which these politicians could start their economic activity or at least provide themselves existentially. In that sense, the corruption of new political and economic structures proves to be a structural phenomenon in peripheral economies. Tocqueville, arguing with Montesquieu, claimed that the secret of despotism is in corruption, and not in fear. Tocqueville did not deny Montesquieu's allegations of fear as the "energy principle" of despotism but only warned that in the "new despotism," which relies less on direct repression and more on forms of manipulated support, the influence of despotism is more significant. Tocqueville will almost repeat Tacitus' great places that "corruption is the most serious disease of the state." It relies on money and sinecure for the stability of rule and power. Money takes the place of opinions and parts, Tacitus teaches, and Tocqueville renews. Tacitus' descriptions of how the rulers ruin the reputation and authority of respectable citizens are among the most beautiful aspects of the Annals. (Schaefer, 2010: 375) He teaches us not only the anatomy of order but reveals the power of moral attitude and civic virtues. A society of ruined virtues is a burdensome bed for both rulers and subjects. For example, Milosevic used this technique extensively, corrupting active and combative followers, and thus kept the rest of the population in complete obedience.

If we look at the Balkans in geographical form through the five former ex-Yu countries, except the Slovenia, it has become a frozen entity in history, due to prevailing ethnonational differences and circumstances between and within borders (nationalism, state sovereignty, and identities) opposing the wave of democratic peace. Political structures in the region are left or right-wing, sometimes opposing each other, and sometimes cooperating in networked systems of mutual support. However, very often, abuse by the government destroys the essence of democracy. Political elites, balancing international pressure, often try to weaken state functions in segments that are not important to the regime's survival, "while expressing actions when it comes to government interests." (Deudney, 2004) This claim is supported by the fact that most ex-Yu countries it has not been able to reach the level of development since the late 1980s, with an increased risk of losing the equity in interaction with other countries. Most countries depend on stand-by arrangements with the International monetary fond (IMF), and some have an Extended Fund Facility (EFF), differing in the extended repayment period. Countries are becoming constantly dependent on external factors, as weak, 
unfinished, and undemocratic state formations that cannot achieve sufficient autonomous - economic, political, social, national and security capacities for progress. Meanwhile, states in the region have become "trapped" or "kidnapped" by private interests after controversial privatizations and the large influence of illegally enriched individuals. (Teokarevic, 2009) All of the above is contained in the fact that international support is given to "political pragmatists" who oppose "rigid legalists" throughout the Balkans, and pragmatism is in the process of political and social transformation of society.

The status quo and lack of qualitative changes maintenance political-interest structures, utterly independent of differences in their proclaimed politicalideological goals. Ethnonationalism does not bring political scenes a socioeconomic system that would already be independently formed, with appropriate bearers of transformative interests and competing "projects" of the new order. Most often, society's strata have no interest in carrying out reforms and supporting political and economic transformation. Political and economic change cannot be fully accomplished due to disagreements between the economic and political spheres that would thwart democratic institutions' functioning because of the consolidation of the democratic order and the establishment. (Hadžić, 2020)

According to experts, if we take the example of Bosnia, it is a country with a favorable geographical position, right climatic conditions, an abundance of arable land, many watercourses and forest, ore, and other resources. How is it possible that such a country ranks last on the European scale of development? Professor E. Bajtal claims that he has been "drawing a sad parallel between a rich country and a poor country" such as Bosnia for years. "In such a complex, rich country, thanks to the absurdity of fraudulent ethno-logic and ethno-democracy, there is a state of poor citizens - a country of produced poverty. The law on the conversion of social property, passed in the middle of the war, provided an opportunity for its bearers to privatize the social, people's property; twenty years after the rule of selfproclaimed guardians of vital national interests, the country is drowning in misery, poverty and "legalized injustice." (Bajtal, 2015)

\subsection{The Illegitimate Legacies of the Yugoslav Wars}

A. Peter (2004) argued that war economies in places like the Balkans, the Caucasus, and Central Asia are criminalized because they rely on criminal actors and the black market as the primary source of funding and supply, within a close connection between conflict and crime, which gives these conflicts the form of criminalized conflicts. An important economic feature of the war in the former Yugoslavia is the explosion of so-called war profiteers. The judiciary, the laws of Yugoslav institutions, were transformed into the former Yugoslavia's newly established states. Chaos in Bosnia and Herzegovina is created by the JNA's (Yugoslav People's 
Army) withdrawal, the storage of weapons from Slovenia and Croatia to Bosnia and Herzegovina. The diaries of JNA (Yugoslav peoples Army) General Ratko Mladic, which were seized in Belgrade, describe the details of meetings between representatives of the warring armies, who arrange and carry out millions of transactions. The testimonies of the accused witnesses in the Hague Tribunal (ICTY) investigations and trials further confirm the above.

Since every war is, by definition, a time of abnormal tendencies in all spheres of human life, the most drastic changes in the domain of economic efficiency have taken place. Thus, a unique economic feature and most significant impetus for strengthening criminal networks in the Balkans was the tremendous economic opportunity offered by weapons or other war goods, such as fuel, and appropriation of international humanitarian aid. At the same time, Western policy was based on a cynical view of the strategic loss of value of the Balkans after the Cold War. Despite the „Western neutrality" for material support to the parties in the struggle and thus the prolongation of the conflict, humanitarian aid that was salty was taken away during that period by many warlords, (Rieff, 2003), who did not differ, for example, from Somali factions. In the past, international humanitarian discourse from similar experiences in Somalia has not been sufficiently understood. Even in the case of the implosion of the earth, the trigger was a sudden "collapse of strategic value." On the example of the war in Somalia, J. Gundel proved that international food aid served to maintain structures ruled by violence and warlords and contribute to the maintenance of precisely those structures that led to the catastrophic famine. Within humanitarian discourse in former Yugoslavia, confiscation occurred on the mutually established war lines of the warring parties, or in the continuous practice that domestic humanitarian organizations mainly performed the organization of taking over and distribution of humanitarian goods. Moreover, in Sarajevo alone, each truckload of "imported," often smuggled excise goods meant close to millions, and it was not uncommon for goods to be of unknown origin and without proper production and trade documentation. Closely related interest groups of political-military-business individuals among all warring parties became multi-millionaires in less than four years of war, and several of them accumulated capital of up to a billion. (Basic, 2006: 138) On the example of the post-war situation in Bosnia and Herzegovina, M. Pugh showed how strongly political and economic interests are intertwined with controlling over trade and production. Bosnia and Herzegovina is also an excellent example of how the international embargo enabled the creation of many monopoly positions based on force and how, partly because of these monopolies, the economic structures of war greatly hinder the construction of a market order in the postwar period. (Pugh, 2002: 467) The conflict in Bosnia did not differentiate between political and criminal, and there is an interaction of political interests and the interests of the crime itself. (Peter, 2004: 3) In this respect, the legacy of the war economy had a profound effect on the post-war processes of social reconstruction. In general, only those who have funds, de facto, and not only formal 
or institutional influence, weapons, de facto power, only these actors can "deliver results," and in former Yugoslavia, such actors are largely criminalized or are very close to a crime.

If we analyze at the material side of local wars, we see that they are intertwined with the global economy. It is especially noticeable in those areas that were the subject of Jean and Rufin's analysis5, namely the international embargo, the diaspora, international aid, and organized crime. At the center of that globalization in the shadows are mafia structures and "warlords". On the one hand, they are representatives of the ruthless and violent exploitation of people and resources in the territory under their rule. On the other hand, in that context, local military control in a given territory is combined with satisfying financial and political interests at the international level. Through the so-called mafia structures of the war economy, illegal markets are also integrated into the formal global economy. The "masters of war" play a dual role in this - they are both local commanders and global entrepreneurs, who invest their war profits in the formal economy. (Jung, 2003: 22) Thus, war economies are made up of dynamic forms of economic reproduction that range from survival through violence, through the financing of military expenditures, to the accumulation and new investment of capital in the world market.

Within the illegal economy, Montenegro's political elite has suffered numerous accusations from the international community of systematic tobacco smuggling, Kosovo and North Macedonia as a profile of hotspots drugs smuggling from Afghanistan through Turkey, and Serbia's political elite in 2001-2004 under "proEuropean reform" ruled allegations of supporting Mafia in exchange for their support for "social reforms."6 At the same time, in these examples, we see that party elites are willing to tacitly or actively participate in these operations, retaining social power despite the impoverishment of society. In all of these cases, criminals have played a key role in strengthening political leaders in countries undergoing a difficult and, in part, unsuccessful "transition." (Köppel \& Szekely, 2002: 6) The links between organized crime and the political top of "transitional democracies" can range from "constant looting," as some call it, "to the complete captivity of the state by organized crime." (Berdal \& Serrano, 2002: 7) Transnational organized criminal networks (Kosovo-Serbia-BiH-Macedonia-Croatia) are a significant source of income and employment, and thus a threat to legitimate social orders. (Hadzovic

\footnotetext{
${ }^{5} \mathrm{~A}$ pioneering contribution to the paradigm shift, the transition from ethnicity to the economy, was given by a collection that appeared in 1996 under the title Economie des guerres civiles edited by Francois Jean and JeanChristophe Rufin. It analyzes the participants' economic strategies and interests in the war in a series of wellresearched cases and shows how both those strategies and those interests are firmly connected with global economic processes.

${ }^{6}$ These are flagrant examples of synergies between the political elite and organized crime because the police alone could never act like this.
} 
\& Airello, 2018) The damage that, say, Bosnia suffers from the illegal economy on an annual basis is estimated at "600 million dollars, which is approximately the same as the budget deficit." (Hadžić, 2020)

The protection of national interests is the safest and most profitable. For this to continue, it is essential to use its influence in the media and encourage a general social climate that will lead the citizens to seek security not in overcoming but, on the contrary, in maintaining ethnic divisions. (Mujkic, 2020) Moreover, the domestic ethnonationalism philosophies are not close to the EU principles and standards, maintaining the status quo in which crime and corruption progress. It is confirmed by the fact that, compared to a few years ago, EU membership is less attractive today for some countries in the Western Balkans, some of which are starting to turn their heads towards new partners, such as Russia. Countries like Bosnia and northern Macedonia, which rely on Russia for oil and gas, are particularly sensitive to Russian incitement to anti-Western and nationalist narratives.

The problems arising from the criminalization of the state arise mainly in environments characterized by the weakness of institutions and the moral crisis that usually accompanies weak institutions. Lawlessness - not only legal but also that embodied in irresponsible thinking - as a rule, suits the strong. Furthermore, the decline in non-thinking, among other things at the point of "self-understanding of war," is an ideal opportunity for not understanding what happened (reduced to war), but it also serves a great extent for its possible prolongation, or its socialization, domestication. , a priori acceptance. Moreover, it is the latter that seems to us to be the greatest danger. Fear and diffusion of insecurity, panic become the main drivers of individual and collective behavior. The values of trust and solidarity are destroyed, the unwritten social contract that shaped and connected the political community does not work, and a special kind of existential fear (fear of disorder) replaces all other types of behavior. In the former Yugoslavia political environment, politicians often act without moral responsibility, nor after the lawsuits against them, and the publicly announced crimes they committed as officials. There is almost no prominent politician in the region who has not been accused of abuse of power. Investigations are mostly not completed, and even if there is a trial, it ends with an acquittal. (Hadžić, 2020)

In one of the dozens of examples (scope of work does not allow detailed analysis), of all ex-Yu countries: the example of $O$. Ivanovic7, who in his last interview before he was killed, described the links between suspicious figures and local authorities in northern Kosovo, saying: the center of power is not inside the municipal building - because the municipal building belongs to this other, unofficial center of power." (Radonjic, 2018) This situation is not exclusively related to the northern part of

${ }^{7}$ Ivanović served as the State Secretary of the Ministry for Kosovo and Metohija from 2008 to 2012 and was also a member of the Coordination Center for Kosovo and Metohija from 2001 to 2008. He was assassinated by unknown perpetrators on 16 January 2018 in North Mitrovica. 
Kosovo: criticism and accusations have long been leveled at former OVK (Kosovo Liberation Army- KLA) commanders who participated in organized crime and turned to politics. 8 Although there are decent legal frameworks in most countries in the region, the prosecution is probably the weakest link in the criminal justice chain in the Balkans. As analysts Florian Bieber and Marko Kmezić (2017) pointed out: "Balkan courts are only independent and autonomous in the legal sense, while in practice the functions of the courts are limited by political influence, inefficiency, nepotism, chronicity, and corruption." The symbiotic relationship between political elites and criminal groups gives the following picture. Political elites provide various types of protection to criminal groups (which may include their family and friends) and their activities, while criminal groups help political elites get rich and gain and retain power. Once power is achieved, it creates an opportunity to improve the protection and legitimacy to cover other activities.

Three internal dimensions determine the space and chances for political corruption: the existence of privileges that politicians can distribute to small groups, the ability of the rich to legally achieve the benefits and longevity of these formed economic and political alliances. These three dimensions increase the willingness of politicians to receive illegal funds for their campaigns, i.e., the mood of tycoons for corrupt politicians. When this kind of cooperation between political elites and criminal organizations is further concretized and developed, then this synergy becomes an organized phenomenon of state crime, in the same way as during Gonzalez's Government in Spain, which was an act of organized state crime.

Most leaders of democratic forces engaged individuals from dubious criminal status, openly known criminals, as their official security, and criminals were often part of political assemblies (Arkan9). Many war commanders emerged from the wars as national heroes, and in the post-war period, became known for illegal enrichment, closely related to power structures. (Cabaravdic, 2008) Many of the war commanders were members of the secret services. Not only did they operate within all the institutions of the system, but they also networked the entire society, so that no actor or event could escape or miss them. (Žunec \& Domisljanovic, 2000: 50) In the party-state, the Services, among other things, were the main selector and creator of the government's map and the certifier of the suitability of their

\footnotetext{
${ }^{8}$ See: Council of Europe, Parliamentary Assembly, Committee on Legal A airs and Human Rights, Inhuman treatment of people and illicit tra cking in human organs in Kosovo, 12. decembar 2010, http://www.assembly.coe.int/CommitteeDocs/2010/ajdoc462010prov.pdf.

${ }^{9}$ Serbian commander of a paramilitary force in the Yugoslav Wars, state agent and state assassin, war criminal, politician and president of the Obilić football club. He was on Interpol's most wanted list in the 1970s -1980s for robberies and murders committed in a number of countries across Europe, and was later indicted by the UN for crimes against humanity for his role during the wars. He was assassinated in 2000 , before his trial could take place. Danas - Google Boeken,2009
} 
holders.10 It is confirmed by reports of members of the intelligence and security forces with political connections who provide support and information to criminal groups to protect them. Thus, many criminals also took part in the war conflicts in the former Yugoslavia (1991-1995). Some of them put themselves at the head of volunteer paramilitary units, i.e., created their private armies, which operated under the command of the regular armed forces of the warring parties, or cooperated with them, or fought for their account and even came into conflict with by the regular police and the army of the states for whose interests those private armies allegedly fought. Due to criminals and others' participation, weakly dependent on the state, warlords, and their gangs in the last wars in the former Yugoslavia, these wars seem like an anachronistic phenomenon, closer to what wars were before the emergence of modern nations and their armies. At the same time, being largely a matter of private initiative, organized crime, the Balkan wars are a novelty, similar to other wars known as "low-intensity conflicts" that erupt after the end of the Cold War period over the past decade. They are a good example of the "postmodern conflicts" according to Swedish Historian P. Englund. These conflicts, in his opinion, have more in common with World War II. I. Čolovic states that regular armies rarely fight postmodern wars in our sense. Instead, cliques, gangs, clans, war hordes are at war." (Colovic, 2005) British historian Marko Hoare (2013) claims that many Bosnian politicians and military commanders were extraordinarily corrupt and emerged from the war as very wealthy.

N. Stjepanović (2017), a researcher at the Humanitarian Law Center, is not surprised by the cooperation between Arkan and Croatian intelligence services. As he claims, the cooperation of criminals from different Yugoslav republics has never stopped. The fact is that the most extreme market for violence is between members of paramilitary units. Moreover, "some of these top criminals maintained close ties with politicians in power and in the further development of these relations, it was sometimes difficult to distinguish who trolled whom." (Latal, 2018: 1) First and foremost, this all too often involves close relationships between political, business, and criminal elites. Furthermore, unlike some countries where criminal groups behave like parasites living at the host country's expense, in many Western Balkan countries, the relationship between state structures and criminal groups is more like a joint venture. (Petrucić, 2014) Power in the Balkans is often based on political clientelism, that is, on giving material goods or benefits in exchange for political support. In societies where the public sector is one of the largest employers, treasury management has a significant impact.11

${ }^{10}$ It is illustrated by the knowledge that, for example, the two most influential politicians in Slovenia, especially in its march towards independence, but also after that, Stane Dolanc and Milan Kučan, arrived in politics from the state security services.

11 See: The Global Initiative Against Transnational Organized Crime, Geneva, p.32,2019 
Moreover, security services can be used to advance the interests of those in power. It is far less common than during the 1990s, but some cases still exist.12 Furthermore, confirmation that clear connections have been established between the security services and criminal groups in Serbia in the past. (Stojarova, 2007: 10) Thus, political clientelism is spreading to the business world.

In such an environment, the boundaries between permitted and impermissible activities become blurred. It provides a favorable and lucrative climate for entrepreneurs who have high-ranking friends, euphemistically described as "controversial businessmen," who manage to evade justice always. Today's critical issue is the concolidation of mutual trust between the phenomena of "politicization of crime and criminalization of politics." (Hadžić, 2020)

\section{Conclusion}

The former Yugoslavia did not suddenly collapse amid the chaotic collapse of communism due to its systemic defects and the spontaneous eruption of ethnic and religious hatred, not because it was communist and authoritarian. In the crises concluded by wars, nationalist leaders who had authoritarian ambitions, and coveted illiberal states, created post-war criminal legacies, taking control of the state apparatus and ownership of economic resources. Ethnonational identities are formed as part of ethnonational-political projects, and national projects imply creating or completing nation-states that lead to the conflict. The presence of capitalism as the ruling model requires the presence of some form of nationalism and national identity- where a certain capitalist elite pragmatically chooses to build a nation-state, to effectively mobilize and homogenize the rest of society on its platform. Paradoxically, nationalist laders are often complicit in undermining their country's sovereignty from within or endangering the national interest for personal gain. Local orders based on ethnic-violence turned into open war economies and entering into dynamic and symbiotic relations with illegal global markets and liberal market structures. All the above was a suitable ground for the flourishing of corruption and business immorality, which was especially favored by the dense and strong ties of the military, political, criminal, commercial structures, and the foundation of the structural factors of the corruption, nepotism, and injustice. The issue is that the foundation grows further and becomes a magnetic element keeping the countries within the mutual consolidation of ethnonationalism, fear of others and national unfreedom.

The author suggests the essence of sometimes misunderstood national issues as a space in which multiple national interests conflict, within multiple national capitals

\footnotetext{
${ }^{12}$ See: European Commission, 'The former Yugoslav Republic of Macedonia: Recommendations of the Senior Experts' Group on systemic rule of law issues relating to the communications interception revealed in Spring 2015', Brisel, 2015.
} 
representing ethnopolitics. In such an environment, the criminal justice system is too often used against those who try to change the status quo, maintaining political-interest structures, utterly independent of differences in their proclaimed political-ideological goals. Politically sensitive cases dealing with corruption, organized crime, or abuse of power are particularly vulnerable to various influences, and therefore it is vital to pass judgments to make existing records credible. In a illegitimate clientelistic ecosystem, institutions often protect those in power, not necessarily the rule of law. Given the actors' social status and power, it is clear that a lack of progressive economic and political transformations are reinforced precisely from the criminalization of the system. The distribution of power characterized by sociopolitical change processes has conditioned the synergy between phenomena and some transitional effects have become structural.

There is no doubt that the mafia participants in the wars were given the national heroes' role with their work and skills. Moreover, the secret services gained sufficient power and knowledge for violent "crisis management". Supporting political rulers linked to organized crime as a strategy to maintain stability undermines the EU accession process. It also discredits the values, credibility, image, and acquis of the EU. Meeting the criteria for EU membership should be seen as a transition goal, not just a condition for membership, which is why it is necessary to focus on the accession process as a key to (economic-political) transformation. The very transformation of all states, in most cases, depends on the social strata and actors of power within states. Most often, society's strata have no interest in carrying out reforms and supporting political and economic transformation. Political and economic transformation cannot be fully accomplished due to disagreements between the economic and political spheres that would thwart the functioning of democratic institutions because the consolidation of the democratic order and the establishment of a market economy are in the balance of incompleteness. Re-establishing social structure and social ties, developing plurality and legality, is crucial as social security, once the most critical issues are met.

All new states, except Slovenia, have found it difficult to decline economically and socially. The war abused the course of economic restructuring and the transition to a market economy. It has led to the widespread criminalization of economies at the heart of the war. Such a historical legacy has persisted and is detrimental to institutional relations and the consolidation of democratic institutions. The critical issue is the consolidation of mutual trust between the phenomena of "politicization of crime and criminalization of politics." When this mutual trust is undermined, more consequential initiatives against corruption can be expected. 


\section{References}

Peter, A., (2004). Criminalized Conflict: The Political Economy of War in BiH, International Studies Quarterly.

Smith, A., (1998), Nacionalni identitet, [National Identity], Belgrade: Library XX. Century.

Tijardević, B., (2016). Kapitalizam, nacionalizam i religija, https://www.radnickafronta.hr/jos-clanaka/271-kapitalizam-nacionalizam-ireligija.

Council of Europe, Parliamentary Assembly, Committee on Legal Affairs and Human Rights, Inhuman treatment of people and illicit tra cking in human organs in Kosovo, (2010).

http://www.assembly.coe.int/CommitteeDocs/2010/ajdoc462010prov.pdf.

Deudney,D.,(2004). Bounding Power: Republican Security Theory from the Polis to the Global Village, Princeton Press.

Rieff, D.,(2003). Bed for night, Humanitarian paradox, Rim, Carocci.

Schaefer, D.,(2010). A Review of "Soft Despotism, Democracy's Drift: Montesquieu, Rousseau, Tocqueville, and the Modern Prospect"Rahe, Paul. New Haven, Yale University Press.

Hadzovic,D \& Aiello,A.,(2018). Western Balkans Serious Crime Initiative (WBCSCi) in the context of Integrated Internal Security Management (IISG Obstacles to implementation in $\mathrm{BiH}$ ).

Jung, D.,(2003). A Political Economy of Intera-State War: Confronting a Paradox Globalization, Ethnic Conflicts and New Wars, A Political Economy of Intra-State War, London, 2003.

Fraenkel, E.,(1952). Dual state, New York.

European Commission, (2018). A credible enlargement perspective for and enhanced engagement with the Western Balkans, Strasbourg,https://ec.europa.eu/commission/sites/beta-

political/files/communication-credible-enlargement-perspective- westernbalkans_en.pdf.

European Commission, (2015). The former Yugoslav Republic of Macedonia: Recommendations of the Senior Experts Group on systemic rule of law issues relating to the communications interception, Brisel . 
Hadžić,F.,(2020). Post-Yugoslav spaces between defective democracies, authoritarianism, and kleptocracies, International Affairs and Global Strategy, Vol 86, 10.7176/IAGS/86-04.

Hadžić, F., (2020). The Politicization of Religion and the Sacralized Balkan Nations Regarding Bosnia and Herzegovina, Occasional Papers on Religion in Eastern Europe: Vol. 40 : Iss. 7 , Article 8.

Hadžić, F. (2020). The political psychology of extremism; "naturalness" of the phenomenon in the Western Balkans. Technium Social Sciences Journal, 11(1), 250267. https://doi.org/10.47577/tssj.v11i1.1519.

Hadžić, F. (2020). The European Union (EU) Political Identity within the migrant crisis, and the Balkan - Bosnian route; xenophobia and religious identity. Research, Society and Development, 9(10), e4809108685. https://doi.org/10.33448/rsdv9i10.8685.

Freedom House, (2018., 2017., 2016). Nation in Transit Bosnia and Herzegovina https://freedomhouse.org/report/nations-transit/2018/bosnia-and-herzegovina.

Freedom House, (2018., 2017., 2016). Nation in Transit Croatia, https://freedomhouse.org/report/nations-transit/2018/croatia,

Freedom House, (2018., 2017., 2016). Nation in Transit Kosovo https://freedomhouse.org/report/nations-transit/2018/kosovo.

Freedom House, (2018., 2017., 2016). Nation in Transit Serbia https://freedomhouse.org/report/nations-transit/2018/.

Stokes, G., (1986). The Social Origins of East European Politics, Eastern European politics and society, https://doi.org/10.1177/0888325487001001003,1986.

Bhabha, H., (1990). Nation and Narration, Routledge.

Interview with Srećko Latal, (2018). Oslobođenje, Sarajevo.

Colovic, I., (2005). Le bordel des guerriers. Folklore, politique et guerre, Munster, LIT François, J. \& Rufin, J.,(1996). Économie des guerres civiles, Hachette, Paris.

Milliken, J. \& Krause,K.,(2002). State Failure, State Collapse and State Reconstruction; Development and Change, https://doi.org/10.1111/14677660.t01-1-00247.

Teokarević,J.,(2009). Democratization of the Balkan Postcommunist Political Systems, Milan Podunavac (ed), State and Democracy, Službeni glasnik i Fakultet političkih nauka, Beograd, ISBN 978-86-519-0949,2009

Jurić, T., (2018). Emigration of Croats to Germany. Are we losing Croatia?,Školska knjiga. 
Köppel T. \&,Szekely A., (2002). Transnational organized crime and conflict in Balkan, Transnational Organized Crime and International Security: Business as Usual?, Kumarian Press.

Kmezić, M. \& Bieber, F., (ur.), (2017). The Crisis of Democracy in the Western Balkans. An Anatomy of Stabilitocracy and the Limits of EU Democracy Promotion, Balkans in Europe Policy Advisory Group Policy Study.

Glavan, M., (2013). The Disintegration of the Socialist Federal Republic of Yugoslavia, master thesis.

Deflem, M., (2012). Max Weber on the rationalization of law, University of South Carolina, Cambridge University Press

Bašić, M., (2006). Fundamentals of war economy - with a review of the war in $\mathrm{BiH}$ 1992-95. UDC 355.018 JEL

Pugh, M., (2002). Postwar Political Economy in Bosnia and Herzegovina, The Global Governance, Vol. 8, No. 4, Lynne Rienner Publishers

Patrucić, M.,2014). Montenegro: Prime minister's family bank catered to organized crime, Organized Crime and Corruption Reporting Project, https://www.reportingproject.net/unholyalliances/prime-ministers-family-bankcatered-to-organized-crime.html.,2014

Kasapović, M., (2001). Democratic Consolidation and Electoral Policy in Croatia 1990-2000, Croatian Politics

Vladisavljević, N., (2011). Constitution and Democracy in the Process of Transformation, Chapter: Democracy, Consolidation of Democracy and the Example of Serbia, University of Belgrade, Faculty of Political Science, Association for Political Science of Serbia

Žunec, O. \& Domišljanović,D.,(2000). Obavještajno-sigurnosne službe Republike Hrvatske: Stanje i načela preustroja za razdoblje konsolidacije demokracije,Polemos 3, https://hrcak.srce.hr/202704

Karklins, R., (2005). The system made me do it - corruption in post-communist societies, M. E. Sharpe, New York

Tabaković, S., (2007). Straight in the head,Zagreb

Woodward, S., (1995). Balkan Tragedy: Chaos and Dissolution After the Cold War, Brookings Inst., Washington

The Global Initiative Against Transnational Organized Crime, (2019). Geneva, Switzerland, https://globalinitiative.net/ 
Hadžić F. (2021). Ethnonationalist Capitalism \& The Illegitimate Legacies of the Yugoslav Wars. BILTURK, The Journal of Economics and Related Studies, 3(2), 87-108.doi: 10.47103/bilturk.853746

Transparency International corruption perception index, (2018). https://www.transparency.hr/hr/clanak/indeks-percepcije-korupcije-2018-48-

bodova-60.mjesto/718

Stojarova, V., (2007). Organized crime in the Balkans, Institute for Comparative Political Research Working Paper for the European Consortium for Political Research Conference, Faculty of Social Sciences, Masaryk University

Vujič, J., (2019). Korijeni Hrvatske kleptokracije, https://projektvelebit.com/korijeni-hrvatske-kleptokracije/

Pavlović, V., (2006). Civil Society and Democracy, Official Gazette, Belgrade Čabaravdic S., (2008). Od ratnih heroja do poslijeratnih junaka, https://www.slobodnaevropa.org/a/1329127.html

Perica, V., (2018). Patuljci pojma nemaju ili Balkanizacija nije nacionalizam, https://pescanik.net/patuljci-pojma-nemaju-ili-balkanizacija-nije-nacionalizam/ 